\title{
XXXIV. Note on the polarization of heat
}

\section{G. Carey Foster F.R.S.}

To cite this article: G. Carey Foster F.R.S. (1877) XXXIV. Note on the polarization of heat, Philosophical Magazine Series 5, 3:18, 261-262, DOI: 10.1080/14786447708639230

To link to this article: http://dx.doi.org/10.1080/14786447708639230

曲 Published online: 27 Jul 2009.

Submit your article to this journal 준

Џ Article views: 2

Q View related articles $\sqsubset$ 


\section{[ 261$]$}

\section{Note on the Polarization of Heat. By G. Carey Foster, F.R.S.*}

7 HE following determinations of the amounts of heat transmitted by two Nicol's prisms, whose principal sections make different angles with each other, were recently made in the Physical Laboratory of University College, London, by Mr. M. J. Jackson. Although the results amount to nothing more than an additional verification of a relation that is already thoroughly established, I venture to put them on record, not only because such verifications are satisfactory in themselves, but also because the apparatus required for conveniently repeating experiments of this kind is not always at hand.

The source of heat was a rather powerful paraffin-oil lamp (supplied by White, of Glasgow, for use with a Thomson's quadrant electrometer). The rays from the lamp were concentrated by a lens of 7.5 centims. diameter and about 22 centims. focal length, placed so as to produce a real image of the lamp-flame within the silvered reflecting cone of the thermopile. Immediately behind the lens (on the side next the lamp) a double screen of polished sheet brass was placed, whereby the radiation could be cut off or allowed to pass at will. On the other side of the lens came two Nicol's prisms, each about 20 centims. long, and giving a clear circular field about 6.7 centims. in diameter. The prisms are protected at the ends by disks of thin glass, which were left on during the experiments. It is to the possession of these fine prisms, made for me by Mr. C. D. Ahrens, that the possibility of making the experiments with so much ease was due. The thermopile, which was about 95 centims. distant from the lens, was protected from stray radiation by a double hood of tin-plate. The galvanometer was a reflecting instrument of low resistance, on Sir William Thomson's principle, made by my assistant, Mr. Grant. By means of a commutator inserted between the thermopile and the galvanometer, two opposite deflections were obtained for each position of the prisms. In the following Table, the column headed $\delta_{1}$ gives the means of the deflections to right and left when the angle, $\theta$, between the principal sections of the prisms was measured in one direction; and the column headed $\delta_{2}$, the corresponding deflections when this angle was measured in the opposite direction. The numbers denote divisions of the galvanometer-scale.

* Communicated by the Physical Society of London, having been read to the Society on March 3, 1877. 
Mr. J. Ennis on the Physical and Mathematical

\begin{tabular}{|c|c|c|c|c|c|}
\hline \multirow{2}{*}{$\begin{array}{c}\text { Angle between } \\
\text { principal sec- } \\
\text { tions }=\theta\end{array}$} & \multicolumn{3}{|c|}{ Deflections. } & \multirow{2}{*}{$\frac{\delta}{\cos ^{2} \theta}$} & \multirow{2}{*}{$\begin{array}{c}\delta^{\prime} \\
\text { (calculated) }\end{array}$} \\
\hline & $\delta_{1}$ & $\delta_{2}$ & $\begin{array}{c}\text { Mean } \\
\delta .\end{array}$ & & \\
\hline $\begin{array}{r}: \\
0 \\
15 \\
30 \\
45 \\
60 \\
75 \\
90\end{array}$ & $\begin{array}{c}\mathbf{3 2 \cdot 2 5} \\
\mathbf{2 9 \cdot 7 5} \\
\mathbf{2 2 \cdot 7 5} \\
\mathbf{1 4 \cdot 7 5} \\
\mathbf{7} \cdot 75 \\
\mathbf{2 \cdot 2 5} \\
\mathbf{0 . 5}\end{array}$ & $\begin{array}{c}31 \cdot 5 \\
29 \cdot 25 \\
23 \cdot 5 \\
14 \cdot 75 \\
7 \cdot 75 \\
2 \cdot 0 \\
0 \cdot 25\end{array}$ & $\begin{array}{c}31 \cdot 9 \\
29 \cdot 5 \\
23 \cdot 1 \\
14 \cdot 75 \\
7 \cdot 75 \\
2 \cdot 1 \\
0 \cdot 4\end{array}$ & $\begin{array}{l}31 \cdot 9 \\
31 \cdot 6 \\
30.8 \\
29.5 \\
31 \cdot 0 \\
31.7 \\
\ldots \ldots . .\end{array}$ & $\begin{array}{r}31 \cdot 1 \\
29 \cdot 0 \\
23 \cdot 3 \\
15 \cdot 5 \\
7 \cdot 8 \\
2 \cdot 1 \\
0 \cdot 0\end{array}$ \\
\hline & & & Mean ... & $31 \cdot 1$ & \\
\hline
\end{tabular}

The numbers in the last column of the Table are calculated by the formula $\delta^{\prime}=31 \cdot 1 \cos ^{2} \theta$. It will be seen that the observed mean values $(\delta)$ never differ from the corresponding calculated values $\left(\delta^{\prime}\right)$ by a whole division of the scale, which represents about as high a degree of accuracy as can be expected from the method of observation employed, it being impossible to read with certainty to any thing less than half a division: where quarter divisions occur in the Table, they result from taking the means of positive and negative deflections.

XXXV. Physical and Mathematical Principles of the Nebular Theory. By J Асов EnNis, A.M.*

THEE chief objections against the derivation of the stars 1 from a former gaseous diffusion of matter have been these two :- first, that no cause can be discovered for the beginning of rotation in the primitive gaseons condition; and secondly, that this rotation, even if begun, could not become rapid enough to produce a centrifugal equal to the centripetal force, and thus to separate equatorial rings which may break and condense into revolving stars. Both these objections I will now remove.

First. The force of gravity, by its interaction between nebulous masses, must necessarily begin rotation.-Sir Isaac Newton says that "if matter were evenly diffused through a finite space and endowed with innate gravity, it would fall down in the middle of that space and form one great spherical mass; but if matter were diffused through infinite space, some of it would collect into one mass and some into another, so as to form an infinite number of great masses. In this manner the sun and stars might be formed, if the matterwere of a lncid nature." This is sound reason, an unavoidable conclusion. Therefore,

* Communicated by the Anthor. 